WSRC-TR-2003-00477

October 16, 2003

\title{
Characterization of DWPF Melter One Glasses
}

A.D. Cozzi

J.M. Pareizs

Westinghouse Savannah River Company

Savannah River Technology Center

Aiken, SC 29808

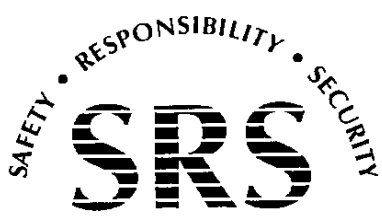

SAVANNAH RIVER SITE

PREPARED FOR THE U.S. DEPARTMENT OF ENERGY UNDER CONTRACT NO. DE-AC09-96SR18500 
This document was prepared in conjunction with work accomplished under Contract No. DE-AC09-96SR18500 with the U. S. Department of Energy.

\section{DISCLAIMER}

This report was prepared as an account of work sponsored by an agency of the United States Government. Neither the United States Government nor any agency thereof, nor any of their employees, makes any warranty, express or implied, or assumes any legal liability or responsibility for the accuracy, completeness, or usefulness of any information, apparatus, product or process disclosed, or represents that its use would not infringe privately owned rights. Reference herein to any specific commercial product, process or service by trade name, trademark, manufacturer, or otherwise does not necessarily constitute or imply its endorsement, recommendation, or favoring by the United States Government or any agency thereof. The views and opinions of authors expressed herein do not necessarily state or reflect those of the United States Government or any agency thereof.

This report has been reproduced directly from the best available copy.

Available for sale to the public, in paper, from: U.S. Department of Commerce, National Technical Information Service, 5285 Port Royal Road, Springfield, VA 22161, phone: (800) 553-6847, fax: (703) 605-6900

email: orders@ntis.fedworld.gov

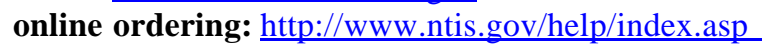

Available electronically at $h$ ttp://www.osti.gov/bridge Available for a processing fee to U.S. Department of Energy and its contractors, in paper, from: U.S. Department of Energy, Office of Scientific and Technical Information, P.O. Box 62, Oak Ridge, TN 37831-0062,

phone: (865)576-8401,

fax: (865)576-5728

email: reports@adonis.osti.gov 
Immobilization Technology Section

WSRC-TR-2003-00477

Savannah River Technology Center

Rev. 0

Westinghouse Savannah River Company

October 16, 2003

\title{
Characterization of DWPF Melter One Glasses
}

\author{
A.D. Cozzi \\ J.M. Pareizs
}

Westinghouse Savannah River Company

Savannah River Technology Center

Aiken, SC 29808

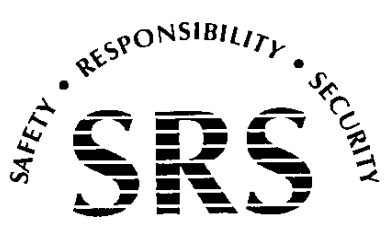

SAVANNAH RIVER SITE

PREPARED FOR THE U.S. DEPARTMENT OF ENERGY UNDER CONTRACT NO. DE-AC09-96SR18500 



\section{Table of Contents}

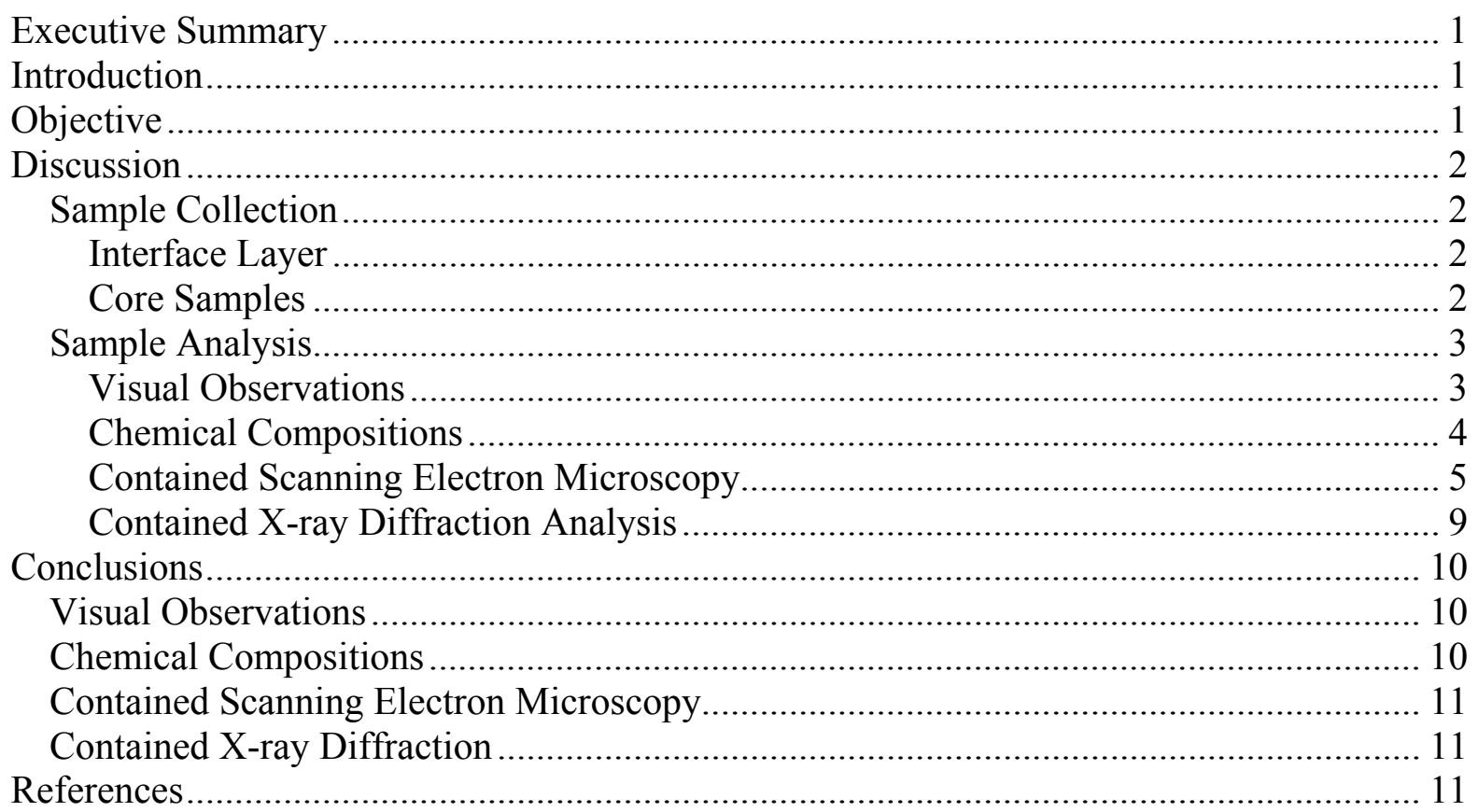


Immobilization Technology Section

WSRC-TR-2003-00477

Savannah River Technology Center

Rev. 0

Westinghouse Savannah River Company

This page intentionally left blank. 


\section{Executive Summary}

The Defense Waste Processing Facility's (DWPF) first melter operated continuously for more than eight years. In November 2002 it was decided to replace the melter. As part of the decommissioning and replacement of the first DWPF melter, three samples were collected from the melter, one from the melter surface and two from the core sampler. The melter samples were analyzed for chemical composition and crystal content.

The interface layer glass appeared as a typical pour stream. The surface was dark and reflective with no obvious inclusions. Little information could be obtained from visual observation of the core glasses. The surfaces were coarse from the sample sectioning.

The materials and methods used to sample to melter core influenced the analytical results. The stainless steel sampler contributed measurable amounts of chromium to the samples. The retrieval of the samples after the melter had cooled permitted the core glasses to crystallize extensively. The crystalline species were consistent with long slow cooling.

The consistency of the compositions throughout the melter, from the interface layer to the two melt pool samples to a previously collected pour stream sample, indicate that there is no measurable stratification of actinides or noble metals.

CSEM/EDS analysis of the core samples suggest that the smooth areas are glass, the inclusions are predominantly iron/silicon compounds and that some of the debris on the surface is alumina from the sectioning blade. CRXD analysis identified the inclusions as aegirine (acmite). CSEM analysis of the interface layer did not reveal any appearance other than glass. CXRD analysis confirmed the amorphous state of the interface layer.

\section{Introduction}

The Defense Waste Processing Facility's (DWPF) first melter operated continuously for more than eight years, including six years of radioactive operations - more than three times its design life. It produced more than 1,300 waste glass canisters, about 27 percent of the projected total canisters for DWPF. In November 2002 it was decided to replace the melter. Prior to melter shutdown, one sample was taken and a sampler was put in place to retrieve additional samples from the melt pool.

SRTC delivered four samplers to DWPF to collect samples. Two samplers were designed to remove a surface sample from the melt pool while the other two samplers were designed to remove core samples to provide a cross section of the melt pool.

As part of the decommissioning and replacement of the first DWPF melter, three samples were collected from the melter, one from the melter surface and two from the core sampler. The melter samples were analyzed for chemical composition and crystal content.

\section{Objective}

The objective of this task is to inspect, characterize and evaluate glass samples from the melter surface and the melt pool. The interface layer was sampled to provide data to aid in the identification and cause of the layer ${ }^{1}$. Two samples of the melt pool were obtained from two depths in the melter. Two depths were chosen to compare relative concentrations of noble metal and actinides to evaluate 
concerns regarding settling of denser species. It should be recognized as the melt pool samples cooled in the melter, no definite conclusions could be drawn from the amount of crystalline species present.

\section{Discussion}

\section{Sample Collection}

\section{Interface Layer}

A platinum boat sampler was used to sample of the interface layer from the surface of the glass pool that remained after the cold cap was burned off (prior to melter shutdown). The interface layer sample was taken through the north feed tube nozzle, approximately two feet north of melter center. The sampler was lowered into the melter by the crane until it just broke the surface and filled with glass. It was then lifted out and allowed to cool. The interface sample was removed from the boat using the extractor provided by DWPF Engineering. Slightly more than 45 grams of sample were retrieved from the platinum boat. It is believed that a representative sample of the surface layer was obtained during the sampling.

\section{Core Samples}

Two samples from the core of the melt pool were obtained from different heights in the melter. The core samples were also obtained through the north feed tube. After glass draw-down via the pour spout was completed, leaving approximately 16 inches of glass in the melter, the stainless steel core sample tube was slowly lowered into the pool till it hit bottom. It was then left in place during melter cooldown. Figure 1 shows the average cooling schedule of the upper and lower thermocouples. It is assumed that the core samples experienced a cooling curve bounded by the two curves in Figure 1 . The melter cooled over several days ${ }^{2}$, Figure 1. Upon retrieval, the bottom of the sampler broke off and remained in the melter, discontinuing the attempt to sample the very bottom of the glass pool. The remaining sampler was sectioned with a predominantly aluminum oxide saw to retrieve the "upper" and "lower" core samples. DWPF-Engineering estimated that the lower sample was four to six inches above the melter bottom and the upper sample was ten" to fifteen inches above the bottom. An effort was made to retrieve glass from the interior of the core samples. The extractor used for platinum boat samples was used to punch out glass near the center of the core samples. This was done to minimize the influence of the stainless steel sampling tube on the composition and crystallization products of the glass. 


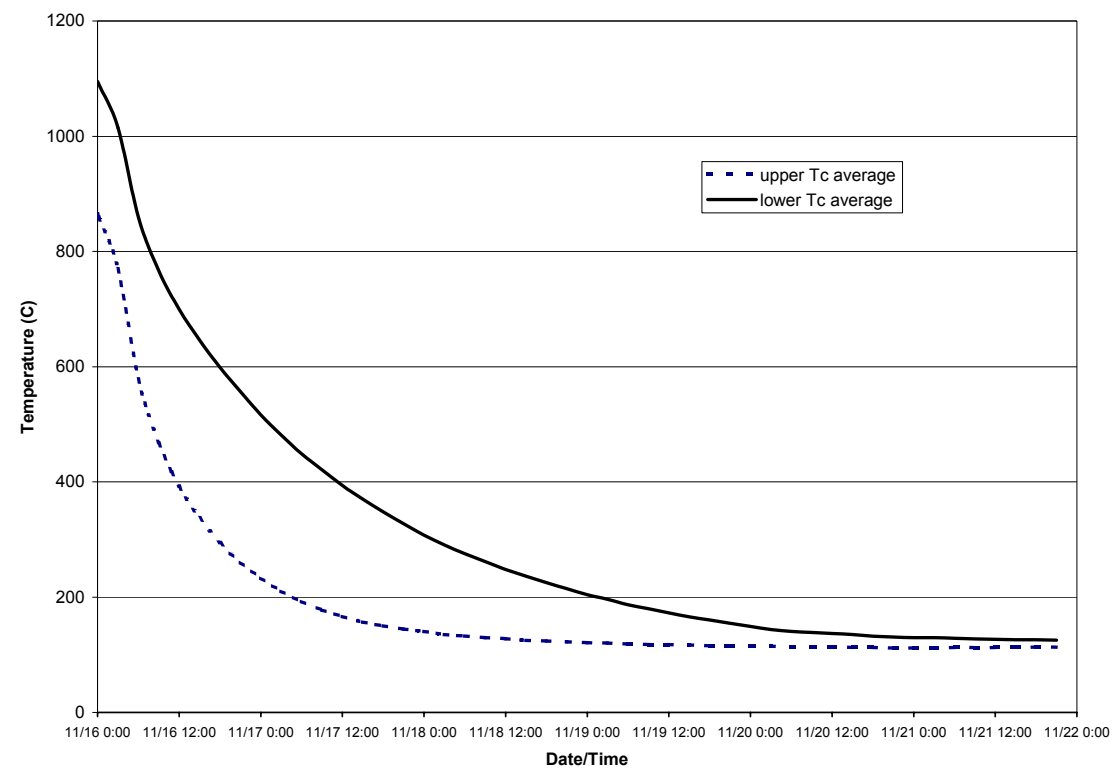

Figure 1. Measured Cooldown Rate of melter one.

\section{Sample Analysis}

\section{Visual Observations}

The three (one interface layer and two core) samples were placed in the Savannah River Technology Center (SRTC) Shielded Cells, removed from their primary containers, and photographed. Figure 2 is A) the interface layer sample and B) the lower core sample (The upper core sample appeared comparable to the lower core sample). The interface sample was contained in a platinum sampling boat and appeared black and shiny similar to previous pour stream samples ${ }^{3}$. The surfaces of both of the core samples were coarse and low luster from the sectioning procedure. It also appeared that the cutting process smeared the stainless steel sampler across some of the glass surface.
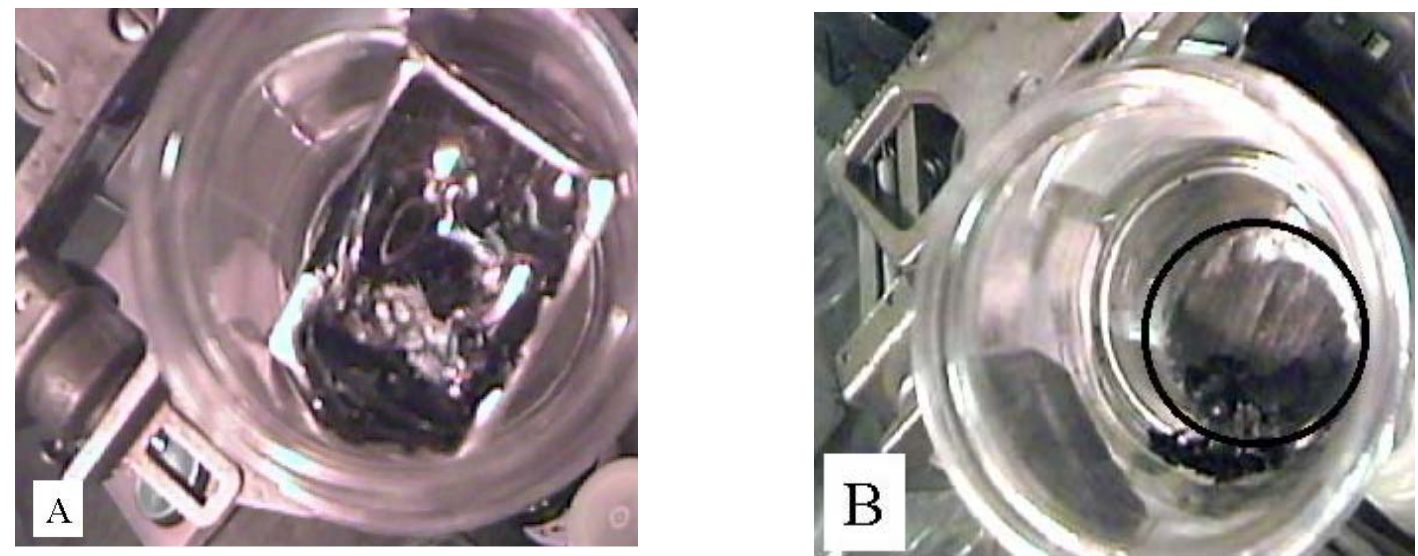

Figure 2. A) Interface layer in platinum sampler, and B) lower core sample in stainless steel sampler (within black circle). 


\section{Chemical Compositions}

Samples were prepared for dissolution by pulverizing a portion of the sample using agate balls and vial. Four replicates of each of the glass samples were dissolved by two methods ${ }^{*}$ to account for all of the elements of interest. The resulting solutions from the dissolutions were analyzed by Inductively Coupled Plasma-Atomic Emission Spectrometry (ICP-AES) by the SRTC Analytical Development Section (SRTC-ADS). Table 1 is the average composition of four replicates of the three samples. Boron and silicon values are determined from the sodium peroxide/sodium hydroxide dissolution. The use of boron in the acid dissolution method precludes the use of boron values reported in acid dissolution samples. Sodium and zirconium values are determined solely from the acid dissolution method. The use of sodium peroxide and sodium hydroxide to perform the fusion in zirconium crucibles excludes the use of reported sodium and zirconium values obtained by this method. In the upper core sample, two of the acid dissolutions were incomplete (oxides did not total $>95 \%$ ) and were discarded. In the lower core sample, one of the acid dissolutions was incomplete (oxides did not total $>95 \%$ ) and was discarded. The composition of the interface layer is similar to both core samples as well as a pour stream sample taken in $\mathrm{FY}_{02} 2^{3}$.

Table 1. Composition of the Interface Layer Glass and the Core Glasses with Previously Reported Composition from a Pour Stream Glass (Wt.\%) (NM-Not Measured).

\begin{tabular}{|c|c|c|c|c|}
\hline & Interface Layer & Upper Core & Lower Core & Pour Stream* \\
\hline $\mathbf{A l}_{\mathbf{2}} \mathbf{O}_{\mathbf{3}}$ & 4.13 & 4.08 & 4.02 & 4.22 \\
\hline $\mathbf{B}_{\mathbf{2}} \mathbf{O}_{\mathbf{3}}$ & 7.63 & 7.54 & 7.54 & 7.31 \\
\hline $\mathbf{C a O}$ & 1.33 & 1.42 & 1.35 & 1.39 \\
\hline $\mathbf{C r}_{\mathbf{2}} \mathbf{O}_{\mathbf{3}}$ & 0.19 & 0.37 & 0.36 & 0.06 \\
\hline $\mathbf{C u O}$ & 0.02 & 0.02 & 0.02 & 0.07 \\
\hline $\mathbf{F e}_{\mathbf{2}} \mathbf{O}_{\mathbf{3}}$ & 13.09 & 13.38 & 12.93 & 12.29 \\
\hline $\mathbf{L a}_{\mathbf{2}} \mathbf{O}_{\mathbf{3}}$ & 0.02 & 0.04 & 0.04 & 0.02 \\
\hline $\mathbf{L i}_{\mathbf{2}} \mathbf{O}$ & 3.20 & 3.11 & 3.05 & 3.29 \\
\hline $\mathbf{M g O}$ & 2.37 & 2.35 & 2.27 & 2.35 \\
\hline $\mathbf{M n O}$ & 1.54 & 1.51 & 1.47 & 2.14 \\
\hline $\mathbf{N a} \mathbf{O}$ & 11.12 & 10.52 & 10.07 & 11.38 \\
\hline $\mathbf{N i O}_{\mathbf{S i O}}$ & 0.73 & 0.80 & 0.78 & 0.54 \\
\hline $\mathbf{S O}$ & 0.94 & 1.21 & 1.19 & $\mathrm{~N}$ \\
\hline $\mathbf{S i O}$ & 48.96 & 52.36 & 52.36 & 48.73 \\
\hline $\mathbf{T i O}_{\mathbf{2}}$ & 0.04 & 0.04 & 0.04 & 0.05 \\
\hline $\mathbf{U}_{\mathbf{3}} \mathbf{O}_{\mathbf{8}}$ & 3.21 & 3.19 & 3.14 & 3.57 \\
\hline $\mathbf{Z n O}$ & 0.07 & 0.07 & 0.06 & 0.09 \\
\hline $\mathbf{Z r O} \mathbf{O}_{\mathbf{2}}$ & 0.08 & 0.07 & 0.07 & 0.09 \\
\hline $\mathbf{S u m}$ & 98.67 & 102.08 & 100.76 & 52.53 \\
\hline $\mathrm{S}$ & & & \\
\hline
\end{tabular}

* Sampled during filling of canister S01753.

The solutions that resulted from acid dissolution of the three samples also were analyzed to gain more detailed information about the composition of the samples not available by ICP-AES. Noble metals resulting from neutron fission of U-235 and a sampling of other U-235 fission products as well as other select actinides were analyzed by Inductively Coupled Mass Spectroscopy (ICP-MS) and other radioactive species were analyzed by counting. Concentrations in weight percent along with the

\footnotetext{
* ADS-2502 - Sodium Peroxide/Sodium Hydroxide Dissolutions of Sludge and Glass for Elemental and Ion Analysis. ADS-2227 - Acid Dissolution of Glass and Sludge for Elemental Analysis.
} 
respective concentrations measured in the pour stream sample are given in Table 2. The isotopes Co60, Cs-137, Eu-154, Eu-155, and Am-241 were measured by gamma counting. All others were measured by ICP-MS. Results were consistent among the three current (one interface and two core samples) glasses and the previous pour stream glass for the gamma emitters and actinides. Although the core samples were similar in noble metal content, both of the core samples were depleted in noble metals with respect to the interface layer and the pour stream glass. As mentioned in the previous section, incomplete dissolution of the core samples could skew the noble metal concentrations. It is most likely that the undissolved portions of the core glasses consisted primarily of crystals that formed during melter cooldown and that a disproportionate amount of the noble metals would contained in these undissolved crystals and would therefore not be available for measurement via ICP-MS.

Table 2. Isotopic Concentrations (wt.\%) of the Three Melter One Glasses and the Pour Stream Glass. (NR - nor reported)

\begin{tabular}{|c|c|c|c|c|c|}
\hline & Isotope & Interface Layer & Upper Core & Lower Core & Pour Stream $^{3}$ \\
\hline & $\mathrm{Co}-60$ & $1.46 \mathrm{E}-07$ & $1.37 \mathrm{E}-07$ & $1.39 \mathrm{E}-07$ & $1.54 \mathrm{E}-07$ \\
\hline & $\mathrm{Tc}-99$ & $2.96 \mathrm{E}-04$ & $1.52 \mathrm{E}-04$ & $1.34 \mathrm{E}-04$ & $2.75 \mathrm{E}-04$ \\
\hline \multirow{4}{*}{ Z } & $\mathrm{Ru}-101$ & $4.03 \mathrm{E}-03$ & $2.92 \mathrm{E}-04$ & $2.72 \mathrm{E}-04$ & $2.97 \mathrm{E}-03$ \\
\cline { 2 - 6 } & $\mathrm{Ru}-102$ & $3.78 \mathrm{E}-03$ & $2.60 \mathrm{E}-04$ & $2.73 \mathrm{E}-04$ & $2.89 \mathrm{E}-03$ \\
\cline { 2 - 6 } & $\mathrm{Rh}-103$ & $3.90 \mathrm{E}-03$ & $3.19 \mathrm{E}-04$ & $3.33 \mathrm{E}-04$ & $6.22 \mathrm{E}-04$ \\
\cline { 2 - 6 } & $\mathrm{Ru}-104$ & $2.38 \mathrm{E}-03$ & NR & NR & $1.91 \mathrm{E}-03$ \\
\cline { 2 - 6 } & $\mathrm{Pd}-105$ & $1.92 \mathrm{E}-04$ & $2.07 \mathrm{E}-04$ & $1.53 \mathrm{E}-04$ & $2.07 \mathrm{E}-04$ \\
\hline & $\mathrm{Cd}-112$ & $1.06 \mathrm{E}-02$ & $8.95 \mathrm{E}-03$ & $6.43 \mathrm{E}-03$ & $1.06 \mathrm{E}-02$ \\
\hline & $\mathrm{Cs}-137$ & $1.00 \mathrm{E}-04$ & $9.65 \mathrm{E}-05$ & $9.76 \mathrm{E}-05$ & $1.03 \mathrm{E}-04$ \\
\hline & $\mathrm{La}-139$ & $7.14 \mathrm{E}-03$ & $3.91 \mathrm{E}-02$ & $1.07 \mathrm{E}-02$ & $6.54 \mathrm{E}-03$ \\
\hline & $\mathrm{Nd}-143$ & $3.77 \mathrm{E}-03$ & $6.39 \mathrm{E}-03$ & $3.38 \mathrm{E}-03$ & $6.10 \mathrm{E}-03$ \\
\hline & $\mathrm{Eu}-154$ & $9.02 \mathrm{E}-07$ & $9.08 \mathrm{E}-07$ & $9.30 \mathrm{E}-07$ & $8.45 \mathrm{E}-07$ \\
\hline & $\mathrm{Eu}-155$ & $2.26 \mathrm{E}-07$ & $2.65 \mathrm{E}-07$ & $2.56 \mathrm{E}-07$ & $2.52 \mathrm{E}-07$ \\
\hline & $\mathrm{Th}-232$ & $5.94 \mathrm{E}-03$ & $8.14 \mathrm{E}-03$ & $1.13 \mathrm{E}-02$ & NR \\
\hline & $\mathrm{U}-235$ & $1.28 \mathrm{E}-02$ & $1.21 \mathrm{E}-02$ & $1.27 \mathrm{E}-02$ & NR \\
\hline & $\mathrm{U}-238$ & $2.93 \mathrm{E}+00$ & $2.81 \mathrm{E}+00$ & $2.95 \mathrm{E}+00$ & NR \\
\hline & $\mathrm{Pu}-239$ & $4.09 \mathrm{E}-03$ & $4.22 \mathrm{E}-03$ & $4.97 \mathrm{E}-03$ & NR \\
\hline & $\mathrm{Am}-241$ & $3.20 \mathrm{E}-04$ & $3.09 \mathrm{E}-04$ & $3.05 \mathrm{E}-04$ & $2.85 \mathrm{E}-04$ \\
\hline
\end{tabular}

\section{Contained Scanning Electron Microscopy}

For contained scanning electron microscopy with energy dispersive spectroscopy (CSEM/EDS), the samples ranged from eight to twelve milligrams to minimize the interference of radiation with the detector and personnel exposure. The small size of the sample limits the representative nature of the analysis. That is, there is an assumption that the eight to twelve milligram sample is representative of the larger sample from which it was collected. This is fair in homogeneous samples, however, in partially crystallized or otherwise heterogeneous samples the representative character of the sample could be questioned.

The interface layer is uniform across the sample, Figure 3. The debris on the surface is from sample preparation and, when the image is viewed using the backscatter electron imaging (BSI) mode, Figure 4, the debris is of similar overall composition as the main sample (i.e., the "shaded" or color is similar). 


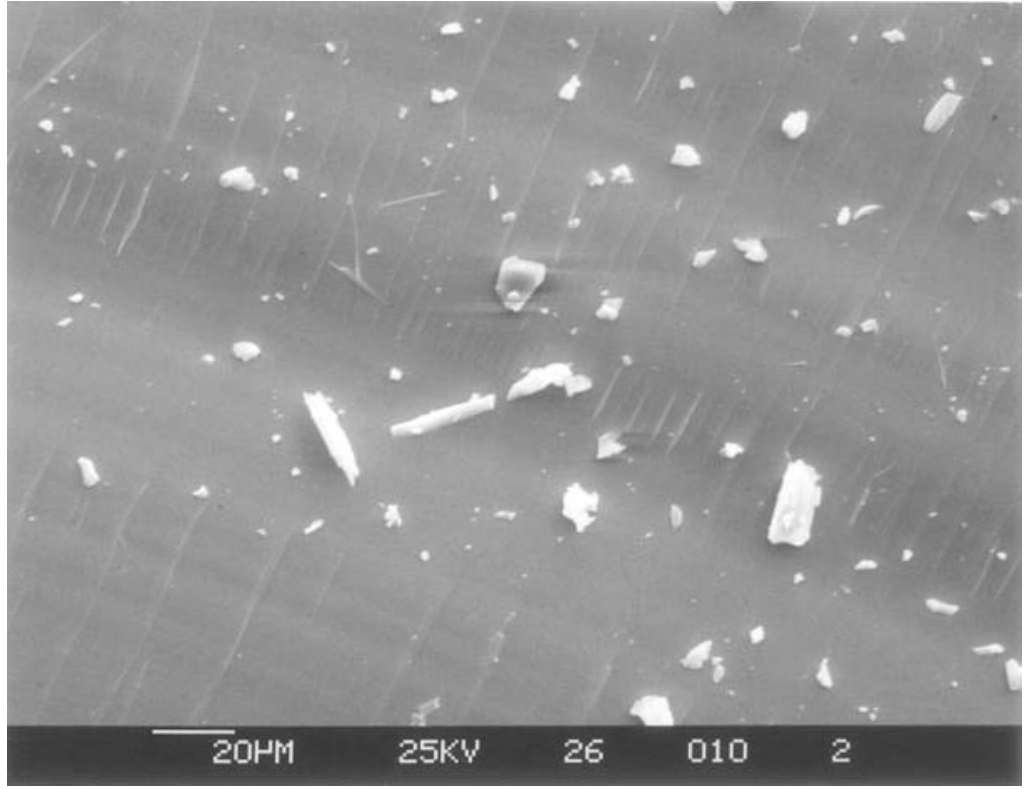

Figure 3. Interface layer glass, 500x.

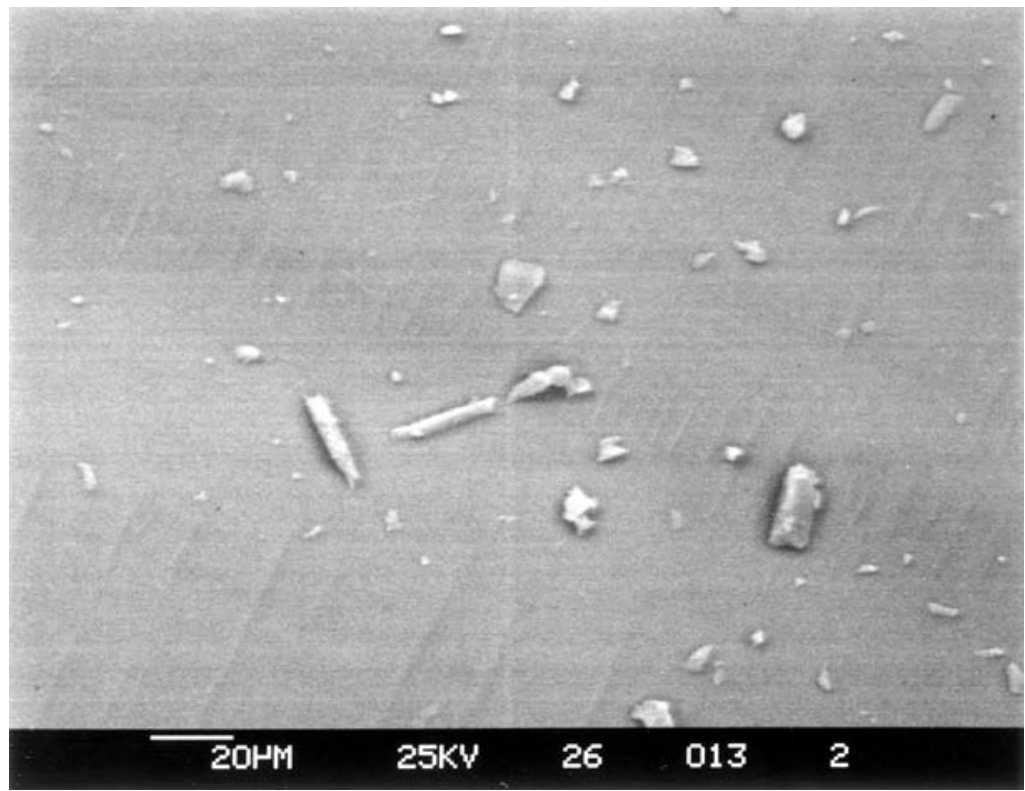

Figure 4. Interface layer glass from Figure 3, viewed using BSI.

The upper and lower core samples exhibited similar features under microscopic examination. Figure 5 is the upper core secondary electron image (SEI) of a typical core particle. The texture of the core samples is indicative of a heavily crystallized glass. The mirror and hackle marks in Figure 5 are confined to areas devoid of inclusions. In addition to the debris seen in the image of the interface layer the glass contains a significant quantity of inclusions. The circled features in the figure are typical of the inclusions noted. 


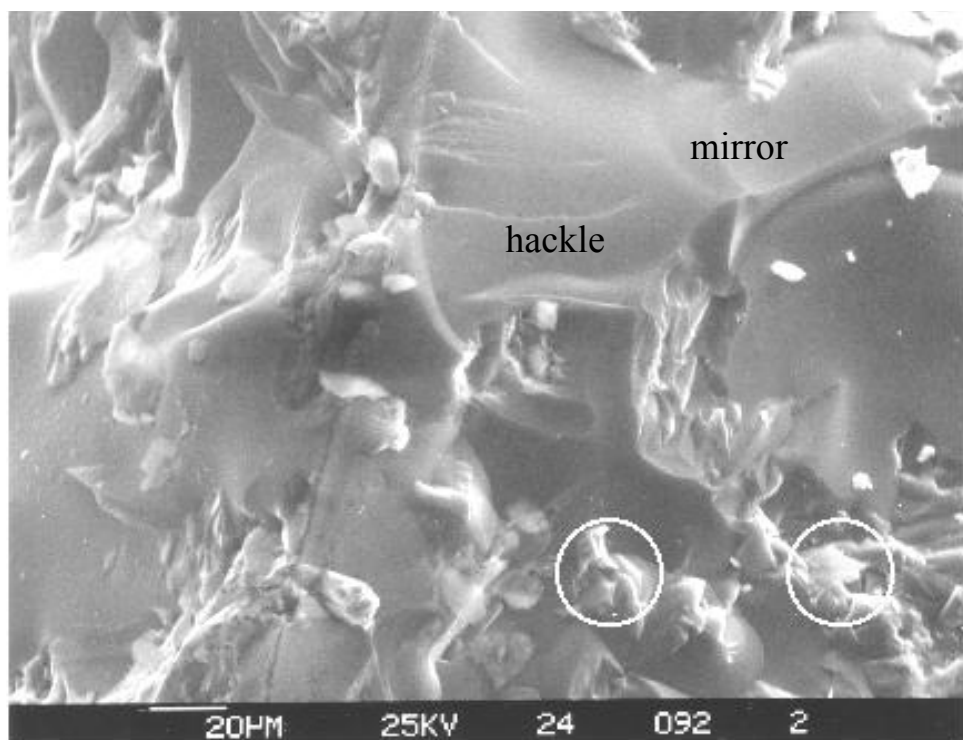

Figure 5. Upper core glass, 500x.

Figure 6 is the BSI image of the sample. Energy dispersive spectroscopy (EDS) evaluations were performed on the spots labeled "A" and "B".

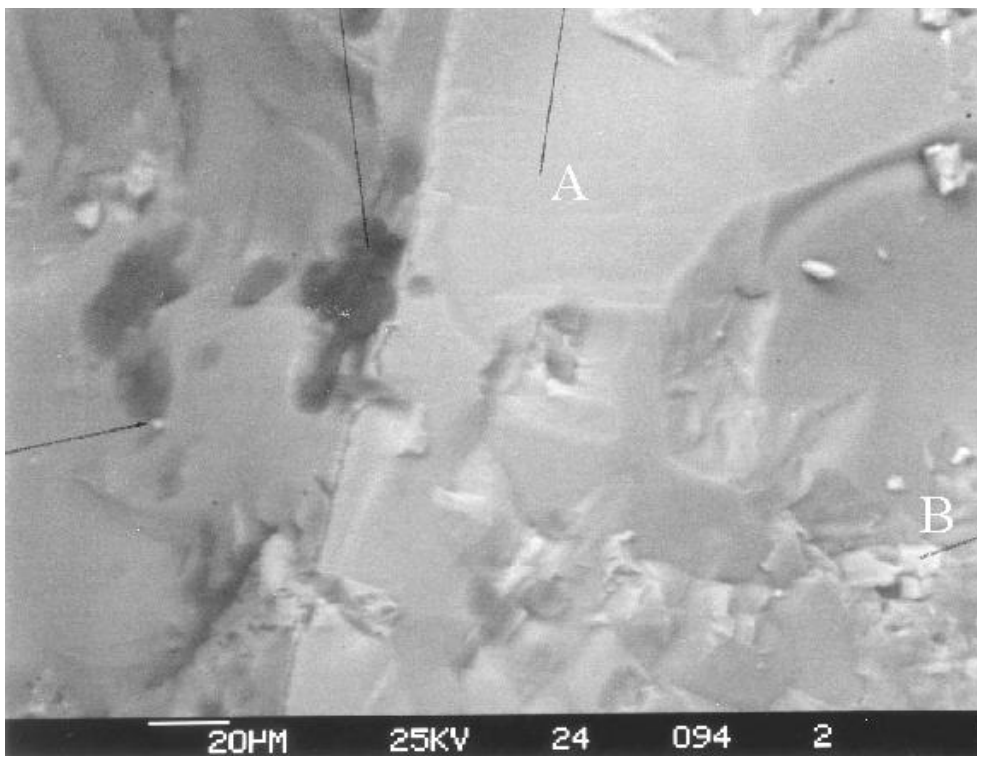

Figure 6. BSI image of upper core glass in Figure 5.

The radioactivity associated with the core glasses limited the ability of the EDS analysis to identify any but the major components of the areas being investigated. The radioactive components can "flood" the EDS detector, limiting the amount of time a spot can be counted. Therefore only sample components with strong signals (from high concentrations) can be easily identified. The interference was such that the EDS analysis was not possible for the interface layer glass. Figure 7 is the associated EDS spectrum of spot "A" in Figure 6 and the corresponding area in Figure 5 and most closely resembles a typical glass sample. Silicon is identified as a major component and iron as a secondary component. The other glass components present in quantities that would be expected to be identified are sodium and boron. In this spectrum, the sodium peak is masked by the leading edge of 
the silicon peak. Boron is too light an element to be detected with this method. The gold (Au) and palladium $(\mathrm{Pd})$ present in all of the spectra is the conductive coating used to prepare the samples. Figure 8 is spot " $\mathrm{B}$ " from Figure 6, which corresponds to the inclusion in Figure 5, identifies iron, in addition to silicon, as a major component of the feature. Aluminum is also identified as part of the area.

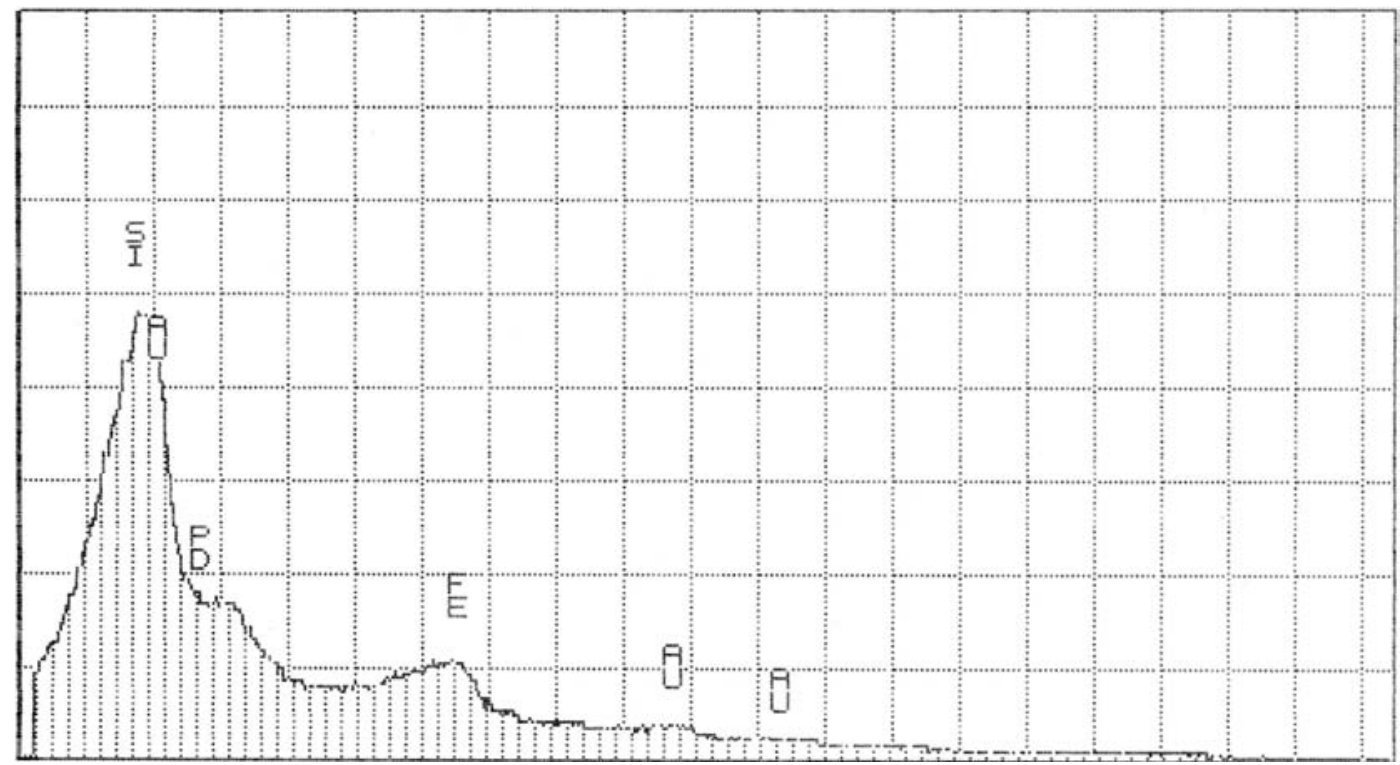

Figure 7. EDS spectrum of Figure 6 spot "A". Au-Pd alloy is used to provide a conductive coating on the sample.

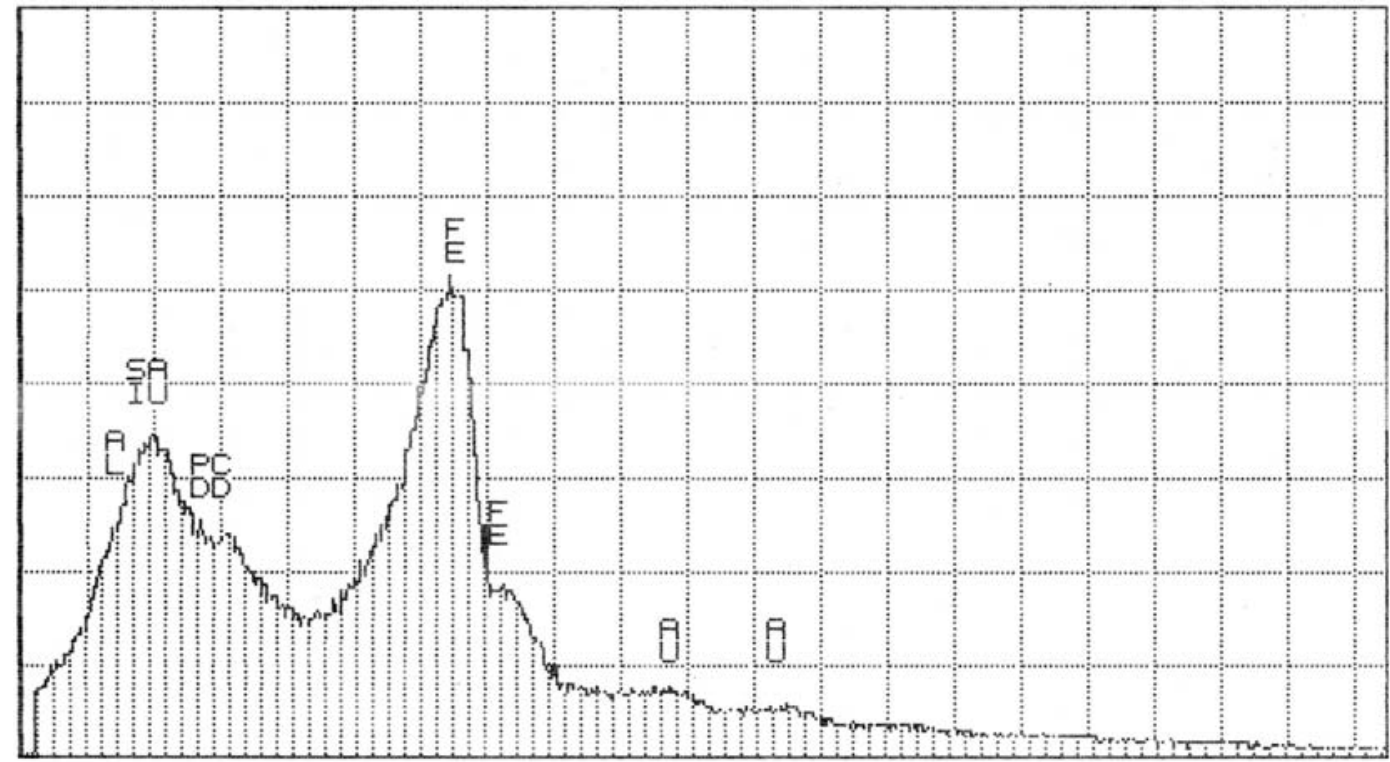

Figure 8. EDS spectrum of Figure 6 spot "B". Au-Pd alloy is used to provide a conductive coating on the sample. 


\section{Contained X-ray Diffraction Analysis}

For contained x-ray diffraction analysis (CXRD), sample masses were between 15 and 35 milligrams. As with the CSEM samples, the small size of the CXRD samples could limit the representative nature of the samples. Although large samples are preferred for improved signal to noise ratios, the ALARA program encourages the minimization of personnel exposure to radioactive samples. The XRD pattern of the interface layer sample was typical of a borosilicate glass and free of any indicators of crystalline matter, Figure 9. As opposed to the interface layer sample that was collected from the melter prior to shut down of the power (and rapidly cooled to room temperature), the core samples were collected after the melter had cooled significantly as shown in Figure 1. The CXRD analyses of the core samples were similar to each other and indicated the presence of three distinct phases. Along with the amorphous hump associated with a glassy phase, a spinel phase and a clinopyroxene phase were identified. The clinopyroxene phase is the major phase and was identified as aegirine (acmite) ${ }^{\dagger}$. The spinel phase most likely resembles trevorite ${ }^{\ddagger}$ as identified in prior DWPF samples ${ }^{3}$. Figure 10 is the CXRD pattern for the lower core sample.

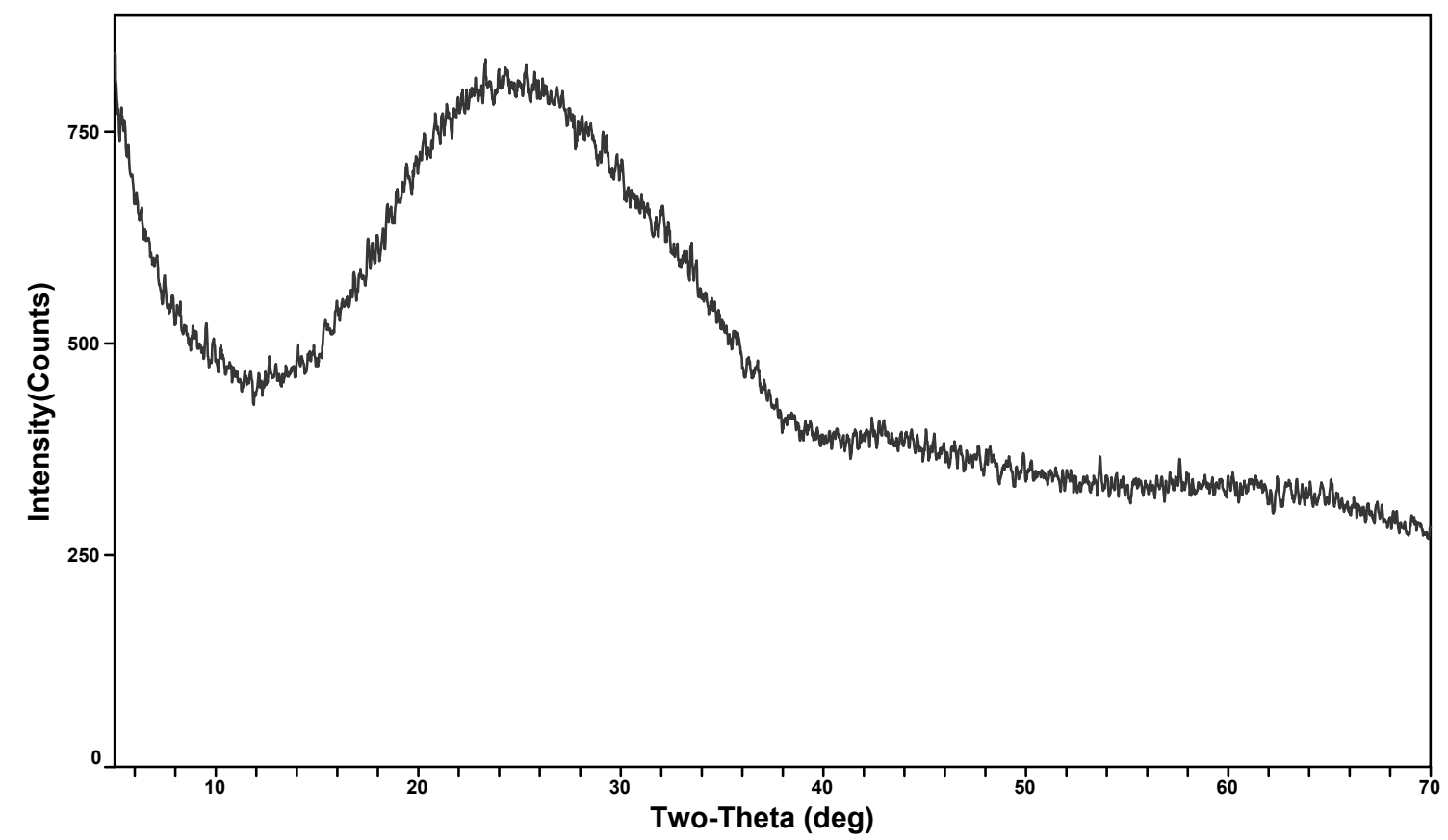

Figure 9. CXRD pattern of the interface layer sample.

\footnotetext{
$\dagger$ Aegirine ICDD card 71-1066 NaFe $\left(\mathrm{Si}_{2} \mathrm{O}_{6}\right)$

* Trevorite ICDD card 10-0325 $\mathrm{NiFe}_{2} \mathrm{O}_{4}$
} 


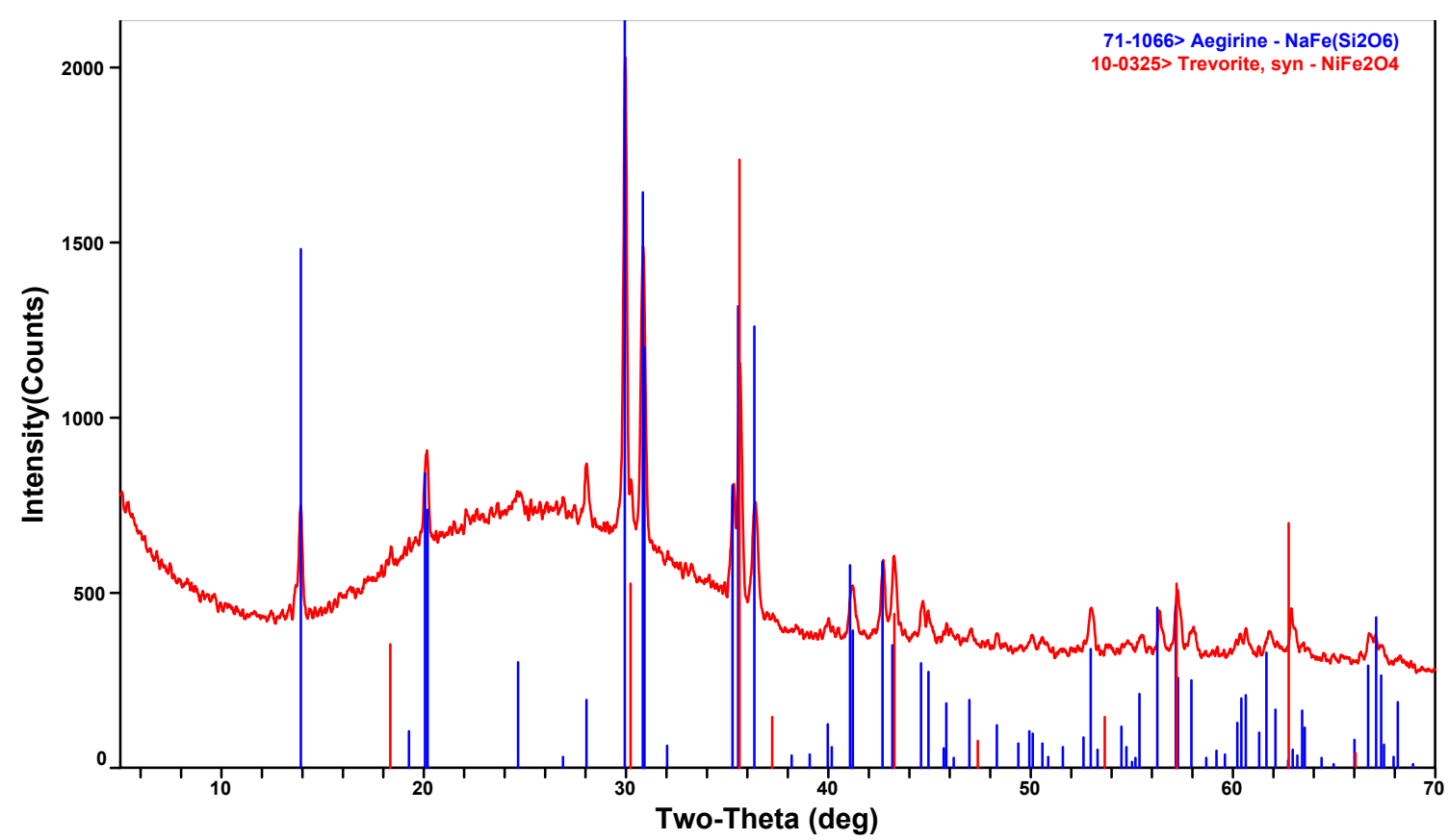

Figure 10. CXRD patter of the lower core sample.

\section{Conclusions}

\section{Visual Observations}

The interface layer glass appeared as a typical pour stream sample as described in Reference 3. It is therefore possible that a sample of the actual interface layer was not obtained. The surface was dark and reflective with no obvious inclusions. Little information could be obtained from visual observation of the core glasses. The surfaces were coarse from the sample sectioning.

\section{Chemical Compositions}

All three of the melter samples, the interface layer, the upper core and the lower core samples, were similar in composition to each other and the pour stream glass sampled in Reference 3 for the elements measured using ICP-AES. Both of the core samples were enriched in chromium. This can be attributed to chromium contribution from the stainless steel sampler. It is evident that the attempt to reduce the influence of the materials of construction of the sampler (stainless steel) on the chemical analysis was not completely successful.

For the elements analyzed by gamma counting (Co-60, Cs-137, Eu-154, Eu-155, and Am-241), the results were consistent among the three melter samples as well as the pour stream sample analyzed previously.

Elements associated with the fission of U-235 were consistent among the three melter samples as well as the pour stream sample analyzed previously with the exception of noble metals in the two core samples. Both the upper and lower core samples were depleted in the noble metals analyzed (Ru-101, $\mathrm{Ru}-102$, Rh-103, and Pd-105). This can be attributed to the sole use of the mixed acid dissolutions for ICP-MS analyses. The core samples both contained significant quantities of crystallized material. 
The mixed acid dissolution is not as aggressive as the fusion dissolution and, based on ICP-AES results, did not fully dissolve the core samples. It is probable that the apparent noble metal depletion in the core samples results from the noble metals participating in the formation of the crystalline phases.

The consistency of the compositions throughout the melter, from the interface layer to the two melt pool samples to a previously collected pour stream sample, indicate that there is no measurable stratification of the more massive actinides or noble metals. These are of interest because increased levels of these elements could contribute to either a criticality concern (actinide segregation) or a reduction in melter life (settling of noble metals).

\section{Contained Scanning Electron Microscopy}

The interface layer glass was uniform in appearance. EDS analysis of the sample was not possible due to the radiation emitted flooding the detector. The core samples were similar to each other in appearance. Both samples had a heavily textured surface with inclusions. EDS analysis suggests that the smooth areas are glass, the inclusions are rich in iron and silicon and that some of the debris on the surface is alumina from the sectioning blade.

\section{Contained X-ray Diffraction}

X-ray diffraction analysis of the interface layer glass indicated that the sample was amorphous. Analysis of the core samples identified aegirine (acmite) and trevorite (spinel) as the two crystalline phases. These results are consistent with results reported during waste glass compositional region development work $^{4-5}$. An amorphous hump in the spectra suggests that significant quantities of amorphous material remain in the sample.

\section{References}

1 D.F. Bickford, D.K. Peeler, M.E. Smith, and D.C. Witt, "DWPF Melter Interface Layer Possible Causes/Solutions Matrix (U), SRT-GPD-2002-00069, July 2002.

2 H.N. Guerrero, "Final Comparison of Predicted vs. Actual DWPF Melter Cool Down Rate," SRT-ETF-2003-00003, January 2003.

3 A.D. Cozzi and N.E. Bibler, "Characterization of DWPF Macrobatch 3 (Mb3) Glass Samples Received 08/13/2002," SRT-GPD-2002-00147, December 2002.

4 C.M. Jantzen, D.F. Bickford, and D.G. Karraker, "Time-Temperature Transformation Kinetics in SRL Waste Glass," in Advances in Ceramics, 8, American Ceramic Society, Westerville, OH pp.30-38 (1984).

${ }^{5}$ C.A. Cicero, S.L. Marra and M.K. Andrews, "Phase Stability Determinations of DWPF Waste Glasses," WSRC-TR-93-227, Rev. 0, May 1993. 
WSRC-TR-2003-00477

Distribution: 